\title{
Paenibacillus tarimensis sp. nov., isolated from sand in Xinjiang, China
}

\author{
Mengxi Wang, † Ming Yang, † Guoling Zhou, Xuesong Luo, Lei Zhang, \\ Yali Tang and Chengxiang Fang
}

Correspondence

Chengxiang Fang

cxfang@whu.edu.cn

\author{
College of Life Sciences, Wuhan University, Wuhan 430072, PR China
}

\begin{abstract}
A Gram-positive, rod-shaped, motile, spore-forming bacterium, strain SA-7-6 ${ }^{\top}$, was isolated from desert soil in China and was subjected to a polyphasic taxonomic study. The strain grew optimally at $\mathrm{pH} 7.5$ and $37^{\circ} \mathrm{C}$. The $\mathrm{G}+\mathrm{C}$ content of the genomic DNA of strain SA-7-6 ${ }^{\top}$ was $53.7 \mathrm{~mol} \%$. The predominant menaquinone was MK-7. The major cellular fatty acid was anteiso$\mathrm{C}_{15: 0}$. Strain SA-7-6 ${ }^{\top}$ contained meso-diaminopimelic acid in the cell-wall peptidoglycan. 16S rRNA gene sequence analysis showed that the new isolate shared highest similarity with Paenibacillus glycanilyticus JCM $11221^{\top}(96.6 \%)$ and Paenibacillus daejeonensis KCTC $3745^{\top}$ (96.6\%). Based on morphological, physiological, chemotaxonomic and phylogenetic characteristics, strain SA-7-6 ${ }^{\top}$ is considered to represent a novel species of the genus Paenibaillus, for which the name Paenibacillus tarimensis sp. nov. is proposed. The type strain is SA $-7-6^{\top}\left(=\right.$ CCTCC AB $206108^{\top}=$ DSM $\left.19409^{\top}\right)$.
\end{abstract}

The genus Bacillus was first described by Cohn in 1872, and many of its members have been reclassified in recent years on the basis of 16S rRNA gene-based molecular analysis. Ash et al. (1993) transferred members of Bacillus group 3 to the genus Paenibacillus, which, at the time of writing, comprises 82 recognized species (http://www.bacterio. cict.fr/p/paenibacillus.html). Species belonging to the genus Paenibacillus have been isolated from different ecological habitats such as desert soil (Lim et al., 2006a, b), honeybee larvae (Genersch et al., 2006), warm springs (Saha et al., 2005) and alkaline soil (Yoon et al., 2005). Members produce ellipsoidal spores in swollen sporangia, are aerobic or facultatively anaerobic, and possess anteiso$\mathrm{C}_{15: 0}$ as the major cellular fatty acid and MK-7 as the predominant menaquinone (Shida et al., 1997).

A novel bacterium, designated strain SA-7 $-6^{\mathrm{T}}$, was isolated from desert sand of the Tarim Basin, Xinjiang, China. The sand sample was suspended in sterile distilled water and inoculated on TGY (per litre distilled water: 5 g tryptone, 3 g yeast extract, $1 \mathrm{~g}$ glucose) agar plates for $48 \mathrm{~h}$ at $37{ }^{\circ} \mathrm{C}$. For subsequent study, the isolate was cultured on trypticase soy agar (TSA) [per litre distilled water: $30.0 \mathrm{~g}$ trypticase soy broth (TSB; Difco), $16.0 \mathrm{~g}$ agar, adjusted to $\mathrm{pH} 7.5$ ] at $37{ }^{\circ} \mathrm{C}$ for $16 \mathrm{~h}$, which were the optimum conditions to gain cells in the exponential phase of growth.

†These authors contributed equally to this work.

The GenBank/EMBL/DDBJ accession number for the 16S rRNA gene sequence of strain $\mathrm{SA}-7-6^{\top}$ is EF125184.
Isolation of the genomic DNA of strain SA-7-6 ${ }^{\mathrm{T}}$ was carried out according to the methods described by Yoon et al. (1996). Fragments comprising the nearly full-length 16S rRNA gene were amplified by PCR with primers $12 \mathrm{R}\left(5^{\prime}-\right.$ GAGTTTGATCCTGGCTCAG-3') and 13F (5'-AGAAAGGAGGTGATCCAGCC- $3^{\prime}$ ). The PCR products were then sequenced by Invitrogen Corporation, where a 1462-bp stretch was gained. Identification of phylogenetic neighbours and calculation of pairwise 16S rRNA gene sequence similarity values were achieved by using the EzTaxon server (http://www.eztaxon.org/; Chun et al., 2007). Strain SA$7-6^{\mathrm{T}}$ showed highest 16S rRNA gene sequence similarity to Paenibacillus glycanilyticus JCM $11221^{\mathrm{T}} \quad(96.6 \%)$, Paenibacillus daejeonensis KCTC $3745^{\mathrm{T}}$ (96.6\%) and Paenibacillus xinjiangensis KCTC $3952^{\mathrm{T}}$ (96.3\%). Levels of sequence similarity to the type strains of other members of the genus Paenibacillus were below 96.3\%. Multiple alignments were performed and a phylogenetic tree based on $16 \mathrm{~S}$ rRNA gene sequences was constructed by using MEGA3.1 software (Kumar et al., 2004). Sequence alignment was achieved by using the CLUSTAL $\mathrm{W}$ method (Thompson et al., 1994). The model of Jukes \& Cantor (1969) was used to compute evolutionary distances, based on which a phylogenetic tree was constructed by using the neighbourjoining method with bootstrap analysis of 1000 replications (Fig. 1) (Saitou \& Nei, 1987) and by using the maximumparsimony method (data not shown).

Stackebrandt \& Goebel (1994) have stated that strains showing less than $97.0 \%$ 16S rRNA gene sequence similarity will have levels of DNA-DNA relatedness below 


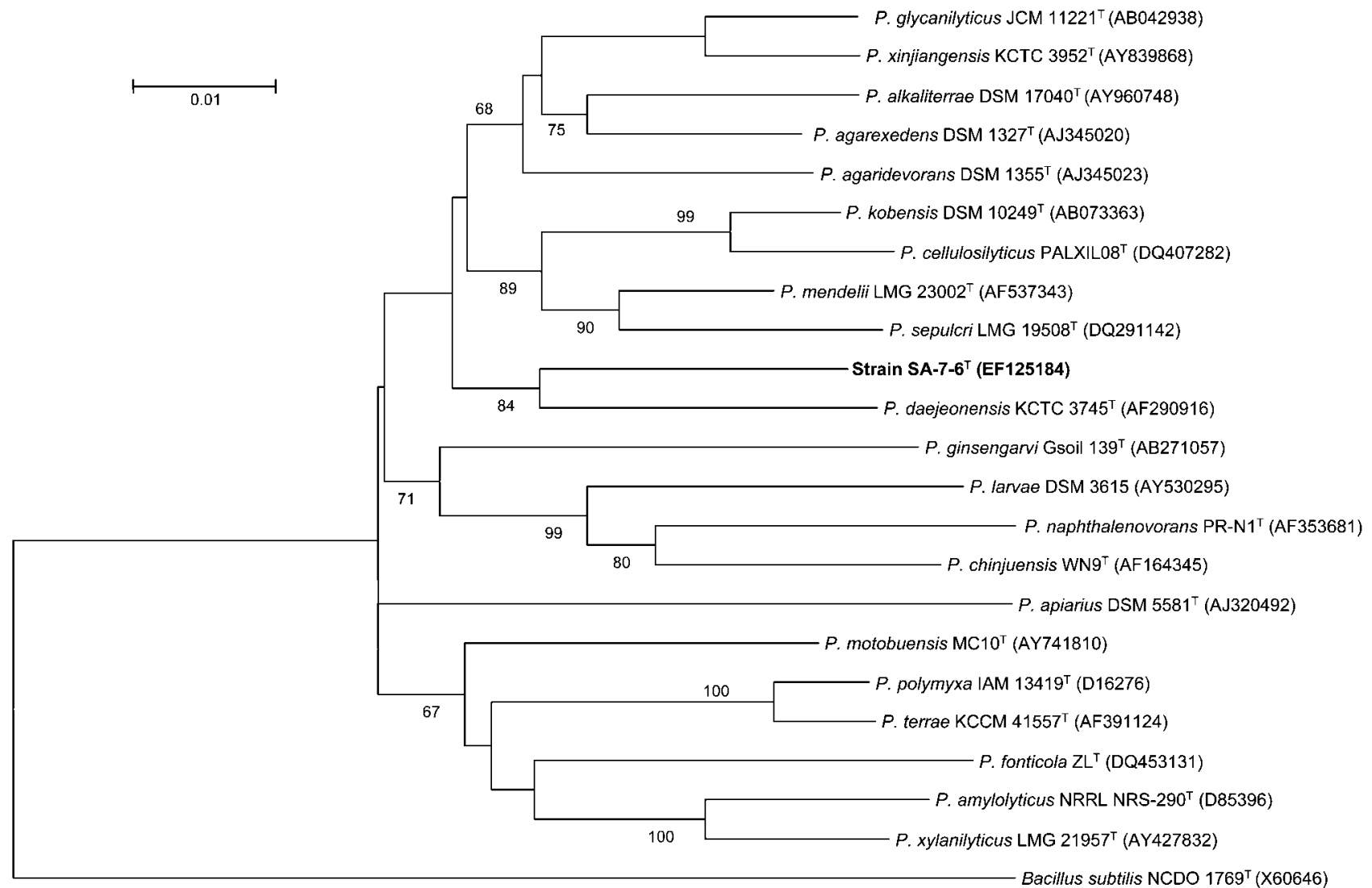

Fig. 1. Neighbour-joining tree based on $16 \mathrm{~S}$ rRNA gene sequences showing the phylogenetic positions of strain $S A-7-6^{\top}$ and other related taxa within the genus Paenibacillus. Reference strains were selected from a comparison of 16S rRNA gene sequences from Paenibacillus species with validly published names. The sequence of Bacillus subtilis NCDO $1769^{\top}$ was used to root the tree. Numbers at nodes indicate levels of bootstrap support based on 1000 resamplings; only values above $60 \%$ are indicated. Bar, $1 \%$ sequence divergence.

$70 \%$. Given this accepted standard for the definition of bacterial species, strain SA-7-6 ${ }^{\mathrm{T}}$ was not related to any recognized species of the genus Paenibacillus.

Cell morphology was examined by phase-contrast microscopy (Olympus). Flagellum type was observed by transmission electron microscopy by using cells from the exponential phase of growth (Fig. 2). Scanning electron microscopy was used to investigate the strain at different growth phases, namely vegetative cells, swollen cells and spores. When grown at $37{ }^{\circ} \mathrm{C}$ for $16 \mathrm{~h}$, strain SA-7-6 ${ }^{\mathrm{T}}$ formed circular, smooth, opaque, ivory colonies on TSA plates, whereas after $24 \mathrm{~h}$ growth under the same conditions, colonies tended to be translucent. Cells were Gram-positive, rod-shaped and motile with peritrichous flagella. They produced ellipsoidal spores in swollen sporangia.

Physiological characteristics were examined by incubating the isolate in basal TSB medium at different temperatures $\left(4,25,30,37,45\right.$ and $\left.50{ }^{\circ} \mathrm{C}\right), \mathrm{pH}$ and $\mathrm{NaCl}$ concentrations (Table 1). Growth was observed at $25-45{ }^{\circ} \mathrm{C}$ (optimum at $37{ }^{\circ} \mathrm{C}$ ) but not at 4 or $50{ }^{\circ} \mathrm{C}$. Growth at different $\mathrm{pH}$

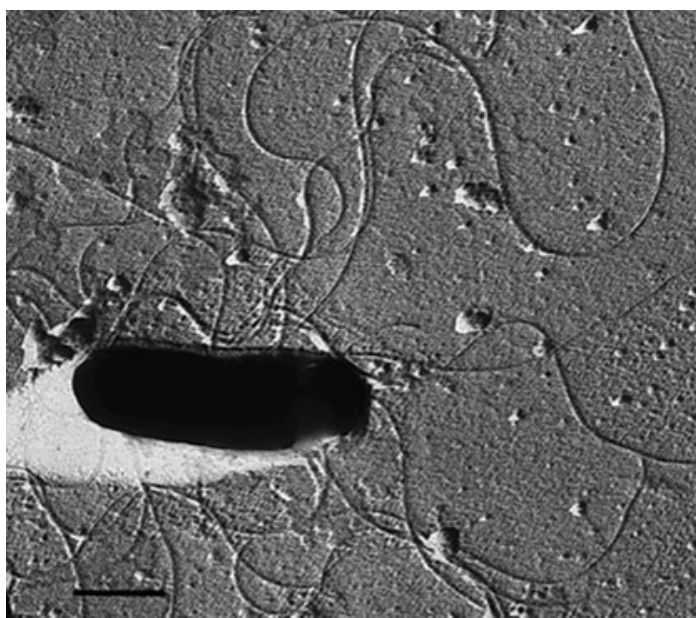

Fig. 2. Transmission electron micrograph of a cell of strain SA-7$6^{\top}$ showing peritrichous flagella. Bar, $1 \mu \mathrm{m}$. 
Table 1. Differential characteristics between strain SA-7-6 and related Paenibacillus species

Strains: 1 , SA $-7-6^{\mathrm{T}}$ (P. tarimensis sp. nov.); 2, P. glycanilyticus DSM $17608^{\mathrm{T}}$ (data from Dasman et al., 2002); 3, P. mendelii LMG $23002^{\mathrm{T}}$ (Šmerda et al., 2005); 4, P. xinjiangensis KCTC $3952^{\mathrm{T}}$ (Lim et al., 2006b); 5, P. daejeonensis KCTC $3745^{\mathrm{T}}$ (Lee et al., 2002). Acids were produced from D-lactose, melibiose and raffinose by all the strains. + , Positive; -, negative; w, weakly positive; V, variable; ND, not determined.

\begin{tabular}{|lccccc|}
\hline Characteristic & $\mathbf{1}$ & $\mathbf{2}$ & $\mathbf{3}$ & $\mathbf{4}$ & $\mathbf{5}$ \\
\hline Gram stain & $\mathrm{V}$ & + & $\mathrm{V}$ & + & $\mathrm{V}$ \\
Anaerobic growth & - & - & + & - & $\mathrm{ND}$ \\
Oxidase & - & - & + & - & + \\
Optimum growth & 37 & $28-37$ & $25-30$ & $30-35$ & 30 \\
temperature $\left.{ }^{\circ} \mathrm{C}\right)$ & & & & & \\
Growth at pH 5.7 & - & + & $\mathrm{ND}$ & - & - \\
DNA G+C content $(\mathrm{mol} \%)$ & 53.7 & 50.5 & 50.8 & 47.0 & 53 \\
Hydrolysis of starch & - & + & - & - & $\mathrm{ND}$ \\
Acid production from: & & & & & \\
Glycerol & - & + & + & + & $\mathrm{ND}$ \\
D-Arabinose & $\mathrm{W}$ & - & + & $\mathrm{ND}$ & $\mathrm{ND}$ \\
L-Arabinose & $\mathrm{W}$ & + & + & + & $\mathrm{ND}$ \\
D-Ribose & - & + & + & + & $\mathrm{ND}$ \\
D-Fructose & - & + & + & + & $\mathrm{ND}$ \\
D-Mannose & + & + & - & + & $\mathrm{ND}$ \\
L-Rhamnose & - & + & + & + & $\mathrm{ND}$ \\
Inositol & - & + & - & $\mathrm{ND}$ & $\mathrm{ND}$ \\
D-Mannitol & + & + & - & - & + \\
N-Acetylglucosamine & - & + & - & $\mathrm{ND}$ & $\mathrm{ND}$ \\
Amygdalin & + & + & - & $\mathrm{ND}$ & + \\
Arbutin & - & + & - & $\mathrm{ND}$ & $\mathrm{ND}$ \\
Salicin & + & + & + & - & $\mathrm{ND}$ \\
Melezitose & $\mathrm{W}$ & + & + & $\mathrm{ND}$ & $\mathrm{ND}$ \\
Glycogen & + & + & + & - & + \\
Turanose & $\mathrm{W}$ & + & + & $\mathrm{ND}$ & $\mathrm{ND}$ \\
D-Tagatose & + & - & - & $\mathrm{ND}$ & $\mathrm{ND}$ \\
& & & & & \\
\hline
\end{tabular}

(5.5-13.5) was investigated in tubes containing $5 \mathrm{ml} \mathrm{TSB}$; $\mathrm{Na}_{2} \mathrm{HPO}_{4} / \mathrm{NaH}_{2} \mathrm{PO}_{4}, \quad \mathrm{Na}_{2} \mathrm{CO}_{3} / \mathrm{NaHCO}_{3}$ and $\mathrm{Na}_{2} \mathrm{HPO}_{4} /$ $\mathrm{NaOH}$ buffers were added to adjust the $\mathrm{pH}$ of the growth medium. After incubation in a rotary shaker at $37^{\circ} \mathrm{C}$, strain $\mathrm{SA}-7-6^{\mathrm{T}}$ grew at $\mathrm{pH}$ 6.0-9.0 (more rapidly between $\mathrm{pH} 7.0$ and 8.0); $\mathrm{pH} 7.5$ was regarded as the optimum $\mathrm{pH}$ for growth. The maximal $\mathrm{NaCl}$ concentration that the isolate was able to tolerate was $3 \%$.

Nitrate reduction, activities of catalase, oxidase, $\beta$-galactosidase, arginine decarboxylase and phenylalanine deaminase, $\mathrm{H}_{2} \mathrm{~S}$ production, indole production, the VogesProskauer reaction, methyl red test and hydrolysis of various compounds were tested on TSA by using the methods described by Smibert \& Krieg (1994). Strain SA-7$6^{\mathrm{T}}$ was positive for catalase, $\beta$-galactosidase, arginine decarboxylase (weakly), phenylalanine deaminase (weakly), the Voges-Proskauer reaction, methyl red test and hydrolysis of aesculin, but negative for oxidase, urease, nitrate reduction, $\mathrm{H}_{2} \mathrm{~S}$ production, indole production, and hydrolysis of starch, casein, gelatin and Tween 80. Acid production was determined by using API $50 \mathrm{CH}$ strips (bioMérieux) following the manufacturer's instructions. Differential characteristics between strain SA $-7-6^{\mathrm{T}}$ and the type strains of closely related Paenibacillus species are presented in Table 1. GP2 Biolog microplates were used to test for the utilization of carbon compounds by strain SA$7-6^{\mathrm{T}}$. Antibiotic sensitivity was tested by adding different antibiotics to tubes containing $5 \mathrm{ml}$ TSB and incubating in a rotary shaker for $24 \mathrm{~h}$ at $37^{\circ} \mathrm{C}$. Strain SA $-7-6^{\mathrm{T}}$ was resistant to kanamycin $\left(10 \mu \mathrm{g} \mathrm{ml}^{-1}\right)$, but not to ampicillin $\left(20 \mu \mathrm{g} \mathrm{ml}^{-1}\right)$, carbenicillin $\left(20 \mu \mathrm{g} \mathrm{ml}^{-1}\right)$ or chloramphenicol $\left(25 \mu \mathrm{g} \mathrm{ml}^{-1}\right)$.

For fatty acid analysis, strain SA-7-6 ${ }^{\mathrm{T}}$ was grown on TSA at $37{ }^{\circ} \mathrm{C}$ for $16 \mathrm{~h}$ until the late exponential phase of growth. Fatty acids were extracted following the instructions of the Sherlock Microbial Identification System (MIDI). The major fatty acid was anteiso- $\mathrm{C}_{15: 0}(47.22 \%)$, which is in accordance with data for other members of the genus Paenibacillus (Shida et al., 1997), followed by $\mathrm{C}_{16: 0}$ $(14.17 \%)$, anteiso- $\mathrm{C}_{17: 0}(13.47 \%)$, iso- $\mathrm{C}_{15: 0}(11.54 \%)$ and iso- $\mathrm{C}_{17: 0}(4.22 \%)$ (Table 2). Distinct quantitative differences were found in the fatty acid profiles of strain SA $-7-6^{\mathrm{T}}$ and $P$. xingjiangensis KCTC $3952^{\mathrm{T}}$, which was also isolated from Xinjiang, China. Strain SA-7-6 $6^{\mathrm{T}}$ showed higher levels of $\mathrm{C}_{14: 0}$, iso- $\mathrm{C}_{15: 0}$, iso- $\mathrm{C}_{17: 0}$, anteiso- $\mathrm{C}_{17: 0}$ and $\mathrm{C}_{16: 1} \omega 11 \mathrm{c}$ but lower levels of iso- $\mathrm{C}_{14: 0}$ and iso- $\mathrm{C}_{16: 0}$ as compared with $P$. xingjiangensis KCTC $3952^{\mathrm{T}}$.

Cell walls were prepared according to the method of Komagata \& Suzuki (1987). The diagnostic cell-wall amino

Table 2. Cellular fatty acid contents (\%) of strain SA-7-6 ${ }^{\top}$ and related Paenibacillus species

Strains: 1, SA $-7-6^{\mathrm{T}}$ (P. tarimensis sp. nov.); 2, P. xinjiangensis KCTC $3952^{\mathrm{T}}$ (data from Lim et al., 2006b); 3, P. polymyxa DSM $36^{\mathrm{T}}$ (data from the present study, as a positive control). ND, Not detected. Fatty acids comprising less than $0.5 \%$ of the total were excluded. All strains were cultured on TSA at about $30{ }^{\circ} \mathrm{C}$.

\begin{tabular}{|lccc|}
\hline Fatty acid & $\mathbf{1}$ & $\mathbf{2}$ & $\mathbf{3}$ \\
\hline Straight-chain saturated & & & \\
$\mathrm{C}_{14: 0}$ & 2.61 & 1.93 & 1.52 \\
$\mathrm{C}_{15: 0}$ & $\mathrm{ND}$ & 3.44 & $\mathrm{ND}$ \\
$\mathrm{C}_{16: 0}$ & 14.17 & 14.43 & 9.25 \\
Iso-branched saturated & & & \\
$\mathrm{C}_{14: 0}$ & 0.84 & 2.12 & 2.01 \\
$\mathrm{C}_{15: 0}$ & 11.54 & 9.32 & 5.91 \\
$\mathrm{C}_{16: 0}$ & 3.74 & 9.62 & 9.64 \\
$\mathrm{C}_{17: 0}$ & 4.22 & 3.54 & 4.35 \\
Anteiso-branched saturated & & & \\
$\mathrm{C}_{15: 0}$ & 47.22 & 48.61 & 47.36 \\
$\mathrm{C}_{17: 0}$ & 13.47 & 4.40 & 14.66 \\
Unsaturated & & & \\
$\mathrm{C}_{16: 1} \omega 11 c$ & 1.55 & 0.53 & 2.49 \\
\hline
\end{tabular}


acid was meso-diaminopimelic acid. Extraction of menaquinone and determination of the menaquinone compositions were carried out by HPLC (Shimadzu) as described by Xie \& Yokota (2003). The predominant menaquinone was MK-7.

The thermal denaturation method (Mandel \& Marmur, 1968) was used to determine the $G+C$ content of the genomic DNA spectrophotometrically (DU800 spectrophotometer; Beckman Coulter). The DNA G + C content of strain SA-7-6 ${ }^{\mathrm{T}}$ was $53.7 \mathrm{~mol} \%$.

On the basis of morphological, physiological, chemotaxonomic and phylogenetic characteristics, strain SA-7-6 ${ }^{\mathrm{T}}$ is considered to represent a novel species of the genus Paenibacillus, for which the name Paenibacillus tarimensis sp. nov. is proposed.

\section{Description of Paenibacillus tarimensis sp. nov.}

Paenibacillus tarimensis (ta.ri.men'sis. N.L. masc. adj. tarimensis referring to Tarim Basin, China, the geographical origin of the type strain).

Cells are Gram-positive, aerobic rods, 3.0-6.0 $\mu \mathrm{m}$ in length and $0.5-0.8 \mu \mathrm{m}$ in width. Motile by means of peritrichous flagella. Ellipsoidal endospores are formed in swollen sporangia. Colonies are circular, smooth, opaque and ivory on TSA plates after $16 \mathrm{~h}$ incubation at $37^{\circ} \mathrm{C}$. Growth occurs at $25-45{ }^{\circ} \mathrm{C}$; optimum temperature for growth is $37^{\circ} \mathrm{C}$. Cells grow at $\mathrm{pH} 6.0-9.0$; optimum $\mathrm{pH}$ is 7.5. Growth is not observed at $\mathrm{NaCl}$ concentrations above $3 \%$. Positive for catalase, $\beta$-galactosidase, arginine decarboxylase (weakly), phenylalanine deaminase (weakly), the Voges-Proskauer reaction, methyl red test and aesculin hydrolysis, but negative for oxidase, urease, nitrate reduction, $\mathrm{H}_{2} \mathrm{~S}$ production, indole production, and hydrolysis of starch, casein, gelatin and Tween 80. Acids are produced from $\mathrm{D}$-xylose, methyl $\beta$-D-xylopyranoside, D-galactose, D-glucose, D-mannose, D-mannitol, amygdalin, aesculin, salicin, cellobiose, maltose, D-lactose, melibiose, sucrose, trehalose, raffinose, starch, glycogen, gentiobiose and D-tagatose, but not from glycerol, erythritol, D-ribose, L-xylose, D-adonitol, D-fructose, Lsorbose, L-rhamnose, inositol, D-sorbitol, methyl $\alpha$-Dmannopyranoside, $\mathrm{N}$-acetylglucosamine, arbutin, D-lyxose, D-arabitol or potassium 2-ketogluconate. Utilizes dextrin, glycogen, cellobiose, D-galacturonic acid, $\alpha$-D-glucose, $\alpha$-Dlactose, maltose, D-mannose, melibiose, methyl $\beta$-Dglucoside, raffinose, salicin, stachyose, sucrose, L-malic acid, succinamic acid, $\alpha$-D-glucose 1 -phosphate, D-glucose 6-phosphate, D-ribose, D-xylose, pyruvic acid methyl ester, succinic acid monomethyl ester and pyruvic acid, but not Tween 40, Tween 80, arbutin, D-sorbitol or $\alpha$-ketoglutaric acid (Biolog GP2 plates). Major cellular fatty acids are anteiso- $\mathrm{C}_{15: 0}, \mathrm{C}_{16: 0}$, anteiso- $\mathrm{C}_{17: 0}$ and iso- $\mathrm{C}_{15: 0}$. Cell-wall peptidoglycan contains meso-diaminopimelic acid. MK-7 is the predominant menaquinone. The $\mathrm{G}+\mathrm{C}$ content of the genomic DNA of the type strain is $53.7 \mathrm{~mol} \%$.
The type strain, SA-7-6 $6^{\mathrm{T}}\left(=\mathrm{CCTCC}\right.$ AB $206108^{\mathrm{T}}=\mathrm{DSM}$ $19409^{\mathrm{T}}$ ), was isolated from desert sand of the Tarim Basin, Xinjiang, China.

\section{Acknowledgements}

This work was supported by the National Infrastructure of Natural Resources for Science and Technology program, Ministry of Science and Technology, People's Republic of China. We would like to thank Dr Akira Yokota, Institute of Molecular and Cellular Biosciences, University of Tokyo, Japan, for quinone analysis.

\section{References}

Ash, C., Priest, F. G. \& Collins, M. D. (1993). Molecular identification of rRNA group 3 bacilli (Ash, Farrow, Wallbanks and Collins) using a PCR probe test. Antonie van Leeuwenhoek 64, 253-260.

Chun, J., Lee, J.-H., Jung, Y., Kim, M., Kim, S., Kim, B. K. \& Lim, Y. W. (2007). EzTaxon: a web-based tool for the identification of prokaryotes based on $16 \mathrm{~S}$ ribosomal RNA gene sequences. Int J Syst Evol Microbiol 57, 2259-2261.

Dasman, Kajiyama, S., Kawasaki, H., Yagi, M., Seki, T., Fukusaki, E. \& Kobayashi, A. (2002). Paenibacillus glycanilyticus sp. nov., a novel species that degrades heteropolysaccharide produced by the cyanobacterium Nostoc commune. Int J Syst Evol Microbiol 52, 1669-1674.

Genersch, E., Forsgren, E., Pentikainen, J., Ashiralieva, A., Rauch, S. Kilwinski, J. \& Fries, I. (2006). Reclassification of Paenibacillus larvae subsp. pulvifaciens and Paenibacillus larvae subsp. larvae as Paenibacillus larvae without subspecies differentiation. Int J Syst Evol Microbiol 56, 501-511.

Jukes, T. H. \& Cantor, C. R. (1969). Evolution of protein molecules. In Mammalian Protein Metabolism, vol. 3, pp. 21-132. Edited by H. N. Munro. New York: Academic Press.

Komagata, K. \& Suzuki, K. (1987). Lipid and cell-wall analysis in bacterial systematics. Methods Microbiol 19, 161-207.

Kumar, S., Tamura, K. \& Nei, M. (2004). MEGA3: integrated software for molecular evolutionary genetics analysis and sequence alignment. Brief Bioinform 5, 150-163.

Lee, J.-S., Lee, K. C., Chang, Y.-H., Hong, S. G., Oh, H. W., Pyun, Y.-R. \& Bae, K. S. (2002). Paenibacillus daejeonensis sp. nov., a novel alkaliphilic bacterium from soil. Int J Syst Evol Microbiol 52, 21072111.

Lim, J.-M., Jeon, C. O., Lee, J.-C., Xu, L.-H., Jiang, C.-L. \& Kim, C.-J. (2006a). Paenibacillus gansuensis sp. nov., isolated from desert soil of Gansu Province in China. Int J Syst Evol Microbiol 56, 2131-2134.

Lim, J.-M., Jeon, C. O., Park, D.-J., Xu, L.-H., Jiang, C.-L. \& Kim, C.-J. (2006b). Paenibacillus xinjiangensis sp. nov., isolated from Xinjiang province in China. Int J Syst Evol Microbiol 56, 2579-2582.

Mandel, M. \& Marmur, J. (1968). Use of ultraviolet absorbancetemperature profile for determining the guanine plus cytosine content of DNA. Methods Enzymol 12B, 195-206.

Saha, P., Mondal, A. K., Mayilraj, S., Krishnamurthi, S., Bhattacharya, A. \& Chakrabarti, T. (2005). Paenibacillus assamensis sp. nov., a novel bacterium isolated from a warm spring in Assam, India. Int J Syst Evol Microbiol 55, 2577-2581.

Saitou, N. \& Nei, M. (1987). The neighbor-joining method: a new method for reconstructing phylogenetic trees. Mol Biol Evol 4, 406-425.

Shida, O., Takagi, H., Kadowaki, K., Nakamura, L. K. \& Komagata, K. (1997). Transfer of Bacillus alginolyticus, Bacillus chondroitinus, 
Bacillus curdlanolyticus, Bacillus glucanolyticus, Bacillus kobensis and Bacillus thiaminolyticus to the genus Paenibacillus and emended description of the genus Paenibacillus. Int J Syst Bacteriol 47, 289-298.

Šmerda, J., Sedláček, I., Páčová, Z., Durnová, E., Smíšková, A. \& Havel, L. (2005). Paenibacillus mendelii sp. nov., from surface-sterilized seeds of Pisum sativum L. Int J Syst Evol Microbiol 55, 2351-2354.

Smibert, R. M. \& Krieg, N. R. (1994). Phenotypic characterization. In Methods for General and Molecular Bacteriology, pp. 607-654. Edited by P. Gerhardt, R. G. E. Murray, W. A. Wood \& N. R. Krieg. Washington, DC: American Society for Microbiology.

Stackebrandt, E. \& Goebel, B. M. (1994). Taxonomic note: a place for DNA-DNA reassociation and 16S rRNA sequence analysis in the present species definition in bacteriology. Int J Syst Bacteriol 44, 846-849.
Thompson, J. D., Higgins, D. G. \& Gibson, T. J. (1994). CLUSTAL W: improving the sensitivity of progressive multiple sequence alignment through sequence weighting, position-specific gap penalties and weight matrix choice. Nucleic Acids Res 22, 4673-4680.

Xie, C. H. \& Yokota, A. (2003). Phylogenetic analyses of Lampropedia hyalina based on the 16S rRNA gene sequence. J Gen Appl Microbiol 49, 345-349.

Yoon, J.-H., Kim, H., Kim, S.-B., Kim, H.-J., Kim, W. Y., Lee, S. T., Goodfellow, M. \& Park, Y.-H. (1996). Identification of Saccharomonospora strains by the use of genomic DNA fragments and rRNA gene probes. Int J Syst Bacteriol 46, 502-505.

Yoon, J. H., Kang, S. J., Yeo, S. H. \& Oh, T. K. (2005). Paenibacillus alkaliterrae sp. nov., isolated from an alkaline soil in Korea. Int J Syst Evol Microbiol 55, 2339-2344. 